\section{INTERNATIONAL In search of a living wage in Southeast Asia}

\author{
Michele Ford \\ Sydney Southeast Asia Centre, University of Sydney, Sydney, Australia, and \\ Michael Gillan \\ Business School, University of Western Australia, Crawley, Australia
}

In search of a living wage in Southeast Asia

Received 28 February 2017 Revised 7 July 2017 Accepted 17 July 2017

\begin{abstract}
Purpose - Debates over the definition, processes and outcomes of minimum and "living" wages are heated and often politically contentious in garment-producing countries. Internationally, there have been various initiatives to promote and support the implementation of a living wage for workers in labourintensive manufacturing, ranging from corporate-driven social responsibility and multi-stakeholder initiatives to the long-standing living wage campaign of the global unions. One prominent regional initiative is the Asia Floor Wage Alliance (AFWA). The purpose of this paper is to assess its reach and effect in Southeast Asia.

Design/methodology/approach - A living wage campaign is assessed with reference to Indonesia and Cambodia, two important garment manufacturing countries in Southeast Asia. The paper draws on data collected in interviews with garment manufacturers, brand representatives, trade unionists and labour NGO activists, including members of the AFWA Steering Committee in Indonesia and Cambodia, complemented by a systematic review of documents and reports produced by the AFWA.

Findings - As the paper shows, despite a series of initiatives, the Asia Floor Wage has failed to gain traction in Cambodia or Indonesia. This is so, the paper argues, because national economic, political and institutional contexts are the primary drivers of the strategies and priorities of constituent organisations, governments and industry stakeholders. In the absence of robust local and regional coalitions of trade unions, efforts towards a common and coordinated regional approach to living wages are thus unlikely to gain traction.
\end{abstract}

Originality/value - To a large extent, the literature on the concepts and practices associated with the living wage has focussed on developed rather than developing countries. This paper extends the literature by providing a systematic examination of a transnational wage campaign in developing Asian countries.

Keywords Indonesia, Cambodia, Trade unions, Living wage, Minimum wage

Paper type Research paper

\section{Introduction}

The status of Southeast Asian countries as labour-intensive manufacturing hubs within global supply chains has drawn international attention to their varying labour standards and employment conditions. International concern over weak social protection and wages for workers in labour-intensive manufacturing across the region is largely focussed on global corporations that source from supplier firms in a region characterised by an evident gap between the formal commitments of states to international labour standards and the reality of their limited capacity and enforcement (Ford and Gillan, 2016). Attention to wages and conditions are most animated in the garment and footwear sector because of the high profile of consumer fashion and leisurewear brands, debate over whether the industry helps or hinders sustainable economic development in nations that are reliant on it for export revenues, links to questions of gender justice given the

(C) Michele Ford and Michael Gillan. Published by Emerald Publishing Limited. This article is published under the Creative Commons Attribution (CC BY 4.0) licence. Anyone may reproduce, distribute, translate and create derivative works of this article (for both commercial and non-commercial purposes), subject to full attribution to the original publication and authors. The full terms of this licence may be seen at http://creativecommons.org/licences/by/4.0/legalcode

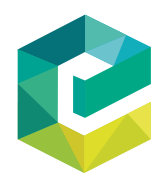

Employee Relations

Vol. 39 No. 6, 2017 pp. $903-914$

Emerald Publishing Limited $0142-5455$

DOI 10.1108/ER-02-2017-0046 
ER

39,6

904

sector's female-dominated workforce, and, of course, the cumulative effect of decades of consumer-focussed union and NGO campaigns. As a consequence of these pressures, debates over the definition, processes and outcomes of minimum and "living" wages are often politically contentious in garment-producing countries.

Garment and footwear manufacturers argue that competitive dynamics in the sector mean that increases to wages and conditions in any single national setting may raise a credible - if exaggerated - threat of a shift in investment and decreased production. Local trade unions and labour NGOs, meanwhile, have focussed on institutional participation and/or worker mobilisation aimed at building pressure for the improvement of wages which so evidently fail to meet the needs of workers and their families (Caraway et al., 2015; Ward and Mouyly, 2016). International activism targeted at the supply chains of international buyer brands has led to a burgeoning apparatus of internal and external mechanisms and organisations for compliance and monitoring. There have been various attempts to promote and support payment of living wages to workers in labour-intensive manufacturing, ranging from corporate social responsibility programs and multi-stakeholder initiatives to the long-standing living wage campaign of the global unions (for an overview, see Maquila Solidarity Network, 2014). One of the most prominent of these living wage initiatives is that driven by the Asia Floor Wage Alliance (AFWA).

How has the approach of the AFWA emerged over time and what are its governing principles? Perhaps even more importantly, what are the prospects for the uptake and implementation of this regional standard given the country-specific institutions that either support or constrain this goal? In the discussion that follows, we seek to answer these questions by means of country case analysis of the reach and effect of the regional living wage strategy in Cambodia and Indonesia, two national contexts that have been a key focus for the AFWA. Our analysis draws on data collected in interviews with garment manufacturers, brand representatives, trade unionists and labour NGO activists, including members of the AFWA Steering Committee in Indonesia and Cambodia, complemented by a systematic review of documents and reports produced by the AFWA[1].

Through our close study of the initiative and local responses to it, we show that local actors have failed to engage because of three key factors. First, as others have argued, there are limitations associated with the methodology used by AFWA to calculate a living wage (Anker and Anker, 2017). Second, while an Asia-wide approach is attractive in theory, in practice it is extremely difficult to resource and sustain such an intervention in a model that seeks to achieve impact across multiple geographic scales and requires the substantive participation of local actors. Third, and most importantly, the idea of the living wage cannot be detached from local labour market and industrial relations institutions and the uneven capacity of workers and unions to assert agency in employment relations, especially where there are national institutions and processes responsible for setting minimum wages.

We begin this task by exploring the concept of the living wage and basic elements of the Asia Floor Wage before turning our attention to the very real challenges involved in strengthening this demand for a regional living wage.

\section{The concept of a living wage}

To a large extent, the literature on the concepts and practices associated with the living wage has focussed on developed rather than developing countries[2]. Thinking about the formulation and realisation of a living wage in a region like Asia accentuates the obvious but crucial significance of context: a living wage campaign in, for instance, a global city like London may indeed target workers who are in low-paid and precarious employment, but constitutes a very different economic and social terrain from developing Asia where labour markets are defined by the structural predominance of informal work and very limited social welfare provisions. Thus, whereas living wage campaigns in Europe or North America may broaden out to incorporate issues such as social inclusion, in developing 
society contexts with "limited employment or trade union rights, where any minimum wage rates are very low and weakly enforced and state systems of social security are rarely provided" (Parker et al., 2016, p. 3).

If actual wages and other economic variables vary, it is also the case that there is no consistent definition of the concept of a living wage or of the best mechanism for its calculation, although in many formulations a basket of goods approach is combined with other means of gathering data on the income, social and health needs of a defined family unit. Yet while the "essential relativism of the living wage concept - defined as it is in terms of higher human needs for social participation and capacity development, both for individuals and their families - makes it difficult to agree on what might constitute an actual living wage in any society at any given point in time" this "conceptual ambiguity" also "opens a space, by necessity, for social mobilisation" (Parker et al., 2016, p. 2). This is a space that the AFWA has sought to occupy both by developing a mechanism for establishing a regional minimum wage - which it claims can be translated into a precise figure in different national settings - and by creating an organisational network to campaign for its establishment.

One of several approaches that have been used in the quest to achieve a living wage in the garment sector in Asia, the Asia Floor Wage is predicated on the need to ameliorate the competition based on wage levels between garment exporting countries and to distribute gains along the supply chain (Merk, 2009). In order to do so, AFWA has identified a living wage that takes into account the food, housing, clothing, travel, education and health costs of a worker supporting a partner and two children (AFWA, 2015c). In itself, this approach is not innovative: it echoes the methodologies already used for minimum wage calculation in Asian countries including India, where wage-fixing authorities are guided by norms on the number of supported consumption units and requirements for food, clothing, housing and other household expenditure items (Government of India, 2012, pp. 12-13) and Indonesia, where minimum wage negotiations are underpinned by a market survey of a basket of goods, food and non-food, predicated on a daily allowance of 3,000 calories (Caraway et al., 2015). Indeed, the Asia Floor Wage calculations consciously adopted Indonesia's 3,000-calorie figure in its formula because that was the highest figure used in the region (Bhattacharjee and Roy, 2012).

In other regards, however, the Asia Floor Wage is quite different from other living wage initiatives, not least because of its operationalization of the principle of establishing a regional standard described in purchasing power parity dollars (PPP\$)[3]. Yet, while acknowledging the importance of the Asia Floor Wage initiative, proponents of other living wage initiatives point to several weaknesses in AFWA's methodology, including its inelastic underlying assumptions regarding expenditure on food and its inability to capture sub-national variations in living costs (Anker, 2011, pp. 38-41). Perhaps most importantly, the proponents of the Anker method argue that the estimation of living costs should focus on particular locations rather than using flat national living wage estimates in order to improve the accuracy and credibility of living wage calculations, and consequently their uptake and impact (Anker and Anker, 2017)[4]. In contrast to this emphasis on sub-national variation, AFWA's demands focus on national standards that equate to an Asia-wide living wage.

\section{The Asia floor wage as a regional living wage strategy}

The second distinctive feature of the Asia Floor Wage is the initiative's Asia-wide focus. Its steering committee includes a number of labour NGO activists from Europe and the USA, most notably the Clean Clothes Campaign (AFWA, 2013). But while the AFWA has support from international civil society organisations, the scope of its activities is limited to Asia - represented in the alliance by Bangladesh, Cambodia, China, Hong Kong, India, Indonesia, Malaysia, Pakistan, Sri Lanka and Thailand (AFWA, 2014b) - and its demands framed as emanating from, and driven by, labour activists based there (Bhattacharjee and Roy, 2015a).
In search of a living wage in Southeast Asia 
ER

39,6

906

Discussions on a union-based strategy to improve Asian garment workers' situation began in India in 2005 (ETI, 2013). In that year, the India Committee on the Asia Floor Wage - a group consisting of a national union federation (New Trade Union Initiative) and a number of labour NGOs - prepared a discussion paper that argued that formulation of a pan-Asian wage would call buyers' bluff by focussing consumer attention on the conditions of garment workers in Asia and strengthen the bargaining capacity of manufacturers vis-à-vis buyers (AFWA, 2005). In the following year, AFWA worked to gather support in key garment-producing countries and to identify a mechanism for calculating a regional living wage. Having estimated that there is approximately a one-to-one ratio between food costs and non-food costs (allowing for modest savings), they decided to calculate the cost of the calorie requirement for three "consumption units" (where one consumption unit consists of one adult or two children), doubling it and multiplying it by 30 in order to estimate the monthly living costs of a worker and his or her family, and then compare them to decide on a PPP $\$$ figure that could serve as a target across the region. This figure was set at PPP $\$ 475$ in 2009 and by 2015 had risen to PPP\$ 1021 (AFWA, 2015c; Bhattacharjee and Roy, 2012).

Having conducted surveys in Bangladesh, China, India, Indonesia and Sri Lanka, AFWA officially launched its campaign on 7 October 2009, writing to dozens of leading brands to challenge them to address unfair pricing as a first step towards the implementation of a living wage (Bhattacharjee and Roy, 2015b). In addition, they developed national-level campaigning and bargaining frameworks for all suppliers in each country; pressured governments to enact legislation that enshrines the concept of an Asia Floor Wage; and lobbied brands, retailers and Tier 1 manufacturers to enter into agreements that facilitate the payment of a living wage (Merk, 2009; Roy, 2015). AFWA later organised "People's Tribunals" in Cambodia, India, Indonesia and Sri Lanka. These events, which were based around the presentation of evidence and testimony from workers and citizens, were focussed primarily on generating evidence on prevailing wage levels in the industry. Associated issues that shape the welfare and labour rights of garment manufacturing workers, including the gendered character of the workplace, trade union rights and the use of short-term contracts, were also discussed (Barria, 2014). In addition, the AFWA produced a video and several reports documenting wages and working conditions in the industry, with the aim of raising consumer awareness and targeting major brands for their responsibility to ensure the payment of a living wage from the suppliers and countries from which they contract (McMullen et al., 2014; Merk, 2014). Yet despite these efforts, and adoption of Asia Floor Wage as a living wage benchmark by a Dutch multi-stakeholder initiative called the Fair Wear Foundation, there has been very little buy-in from major brands.

The AFWA also sought to engage with the Global Union Federations (GUFs) with the aim of building towards the formulation of "a Global Wage Accord, a framework agreement adapted to encompass the entire production network that makes Living Wage in the global garment industry a reality" (Barria, 2014, p. 34)[5]. An initial dialogue between AFWA, the International Trade Union Confederation and a number of GUFs including IndustriALL, the global union with coverage of manufacturing industry, was held in Hong Kong in November 2014 (AFWA et al., 2014). However, in the intervening years, there has been little evidence of concrete examples of jointly developed actions and strategies. IndustriALL has never publicly endorsed the regional approach of the AFWA (Maquila Solidarity Network, 2014, pp. 5-7). Instead, it has pursued its own campaign for supporting improved labour rights, collective bargaining and minimum wages as the pathway to living wages for garment workers (IndustriALL, 2014, 2015), including the Action, Collaboration, Transformation initiative, which involves IndustriALL and several major brands committing to work together to support freedom of association rights and industry-based bargaining in targeted nations, thereby aiming to connect "national industry-level collective bargaining between unions and employers to the purchasing practices of brands" 
(Holdcroft, 2015). This campaign built on the earlier efforts of the International Textile, Garment and Leather Workers' Federation (ITGLWF, 2012)[6]. A weakness, then, of the AFWA initiative has been its failure to bring the key international stakeholders - major brands or the international union movement - on board. Given the transnational ambitions of the Asia Floor Wage, the failure to do so necessarily has serious implications for the effectiveness of the initiative.

The composition of the AFWA is relevant to its apparent lack of integration with international union strategy. While unions and NGOs can form productive and cooperative partnerships, including the alignment of strategic choice in advocating for garment manufacturing workers (Egels-Zandén and Hyllman 2006), there remain important differences in their structures and goals which can be reflected in inter-organisational tensions (Braun and Gearhart, 2004). The AFWA is a union-NGO coalition, in which NGOs play the dominant role. As such, its authority and capacity to coordinate unions internationally is unclear and unproven. Moreover, as noted above, IndustriALL - the global union with a clearer mandate to undertake that coordinating role - has meanwhile developed a parallel strategy for living wages focussed on supporting national industrywide collective bargaining.

\section{The Asia Floor Wage, collective bargaining and wage-setting}

Despite its apparent lack of success engaging with the global unions, the AFWA approach is notable for its emphasis on trade union involvement, which sets it apart from many initiatives for monitoring and improving standards for workers in labour-intensive manufacturing driven by corporations, states or NGOs in various combinations, which are often criticized as both ineffective and in some cases a de facto mechanism of union substitution[7].

The key mechanism envisaged for trade union engagement with the Asia Floor Wage initiative is through coordinated collective bargaining. There are varying forms of bargaining - from decentralized enterprise specific, multi-employer, industry, to nationally coordinated - with several of these linked to the historical development of union strategies to deal with the uneven geography of wages and working conditions by scaling up to nationally coordinated or industry-wide bargaining (Flanagan, 2008). The coordinated forms of collective bargaining at the industry or national level provide for real gains in worker bargaining power, wages and working conditions by taking wages out of the competition. Yet, while there may be a clear logic and imperative for extending wage coordination and bargaining to the supranational level, decades of experiments have failed to replicate the successes of national industry level bargaining because "coordinating labor resistance across national boundaries encounters much more resistance than coordination within a country" (Flanagan, 2008, p. 417). This may be an overly pessimistic assessment insofar as bargaining structures are not static, and can be influenced by the strategic development of various actors over time. It is, however, fair to say that the examples of collective bargaining beyond the national scale are more the exception than the norm.

Where attempts to coordinate wage policies and bargaining have succeeded, as in the metals sector within the European Union, that success has been underwritten by the presence of institutions that provide incentives for such experiments to occur (Pernicka and Glassner, 2014). This could hardly be said to hold true in Asia, where regional union and union-NGO networks are weakly developed (Ford and Gillan, 2016). In an effort to strengthen the engagement of national unions, the AFWA sought to establish an Asia Brand Bargaining Group with the stated intention of bringing together unions from Cambodia, India, Indonesia and Sri Lanka to coordinate bargaining, negotiate with international brands and retailers and ensure local suppliers and subcontracting employers uphold workers' rights and labour laws (Barria, 2014). However, there is little
In search of a living wage in Southeast Asia 
ER

39,6

908

evidence that this initiative has encouraged union participation in meaningful and effective cross-national coordination of bargaining strategies or dealings with major brands (interviews with brand representatives and union officials in Cambodia and Indonesia, November 2016 and January 2017).

In any case, collective bargaining across the region - even when unions are present in garment factories - is weak in terms of both prevalence and effect, which reinforces a central role for state-determined minimum wage processes and outcomes in debates over the economic impact of wage increases. Indeed, there exists a range of state institutions and varying processes for the determination of minimum wages across the region (van Klaveren et al., 2015), which greatly influence wage levels in the garment industry. In some cases, the Asia Floor Wage has been invoked in debates about appropriate levels for the national minimum wage (interviews with Cambodian union officials, January 2017). Ultimately, however, real wage increases (or wage stagnation) are determined by local-level dynamics of the garment industry or via national or sub-national processes of minimum wage determination, which are the locus of most unions' wage-related activity.

\section{Campaigning for a living wage in Southeast Asia}

Before examining the implementation of a living wage campaign strategy in the two selected countries, it is necessary to briefly note the broader demographic and economic context of the garment industry in the Asian region. Asia's export garment-producing countries are clustered in South and Southeast Asia. Within Southeast Asia, garments constitute a significant proportion of manufacturing exports in Cambodia, Indonesia and Vietnam (see Table I).

Indonesia stands out for its larger weight of population, which means that it has the largest number of employed persons in the industry across the region. In terms of export production, however, the garment industry is most dominant in Cambodia, while Vietnam leads strongly in dollar value. Wages are low across the region - with Cambodia and Vietnam at the lower end of the spectrum - and in all instances there is a clear gap between the AFW and the actual monthly minimum wage. Vietnam is not represented in AFWA's membership, which includes organisations from Cambodia, Indonesia, Malaysia and Thailand. Of AFWA's four Southeast Asian members, only Cambodia and Indonesia have hosted People's Tribunals and only Cambodian and Indonesian unions are included in the AFWA's Asia Brand Bargaining Group.

\begin{tabular}{|c|c|c|c|c|c|}
\hline Indicator & Cambodia & Indonesia & Malaysia & Thailand & Vietnam \\
\hline Population (million, 2015) & 15.6 & 257.5 & 30.3 & 68.0 & 91.7 \\
\hline GDP (USD billion, 2015) & 18.0 & 861.9 & 296.3 & 395.2 & 193.6 \\
\hline Manufacturing as \% of GDP (2015) & 17 & 21 & 23 & 27 & 14 \\
\hline $\begin{array}{l}\text { Value of manufacturing exports (USD billion, latest } \\
\text { year to 2015) }\end{array}$ & 7.9 & 66.3 & 133.0 & 159.9 & 132.0 \\
\hline $\begin{array}{l}\text { Garment exports as \% of manufacturing } \\
\text { exports (2015) }\end{array}$ & 76 & 11.5 & 3.6 & 2.3 & 17.8 \\
\hline Employed persons (million, latest year to 2015) & 8.0 & 114.8 & 14.1 & 38.4 & 52.7 \\
\hline $\begin{array}{l}\text { Employed persons in manufacturing (million, latest } \\
\text { year to 2015) }\end{array}$ & 1.6 & 15.5 & 2.3 & 6.3 & 7.6 \\
\hline $\begin{array}{l}\text { Employed persons in the garment industry (million, } \\
\text { latest year to 2015) }\end{array}$ & 0.6 & 2.1 & 0.2 & 0.5 & 1.0 \\
\hline Monthly minimum wage (USD 2015) & 128 & 213 & 253 & 237 & 145 \\
\hline Asia Floor Wage (USD 2015) & 410 & 343 & 386 & 373 & 403 \\
\hline
\end{tabular}

Table I.

The demographic and economic context of the garment industry in the Asian region
Note: The Cambodian figure is for secondary industry, not manufacturing

Sources: AFWA (2015b), ILO (2015a, b), ILOStat (2017a, b), NIS Cambodia (2017), World Bank (2017a, b), and World Trade Organization (2017) 


\subsection{Indonesia}

Indonesia has been one of AFWA's core national locations since the establishment of the Asia Floor Wage initiative. According to the AFWA website, its Indonesian members are the National Workers Union (Serikat Pekerja Nasional (SPN)); the Federation of Independent Trade Unions (Gabungan Serikat Buruh Indonesia (GSBI); the Trade Union Rights Centre (TURC) and the Sedane Institute for Labour Information (Lembaga Informasi Perburuhan Sedane (LIPS)) (AFWA, 2014b). In practice, however, the Indonesian initiative has been primarily driven by TURC, which assumed the role of the Indonesia hub. TURC staff supported the initiative because they felt that the Asian Floor Wage was conceptually sophisticated, but also because they approved of its attempts to bring different types of organisations together across Asia, Europe and America (interview with TURC director, March 2016). By contrast, the garment, textile and footwear unions have showed no interest in substantive engagement, in large part because they felt the Asia Floor Wage calculation was unrealistic, but also because few resources were available to fund-related activities (interviews with representatives of GSBI, SPN and Garteks, March 2016).

The major Asia Floor Wage activity in Indonesia has been the People's Tribunal. Held in June 2014, the tribunal involved members of four unions, including GSBI and SPN, as well as TURC and LIPS. Brands present included Adidas and H\&M, though other major brands including Nike and Gap declined the invitation to attend. Discussions at the tribunal focussed on failure of the Indonesian Government to meet its own commitment to pay a living wage, or indeed even to enforce the payment of minimum wages. Other issues discussed included the use of temporary contracts and factory relocation; union-busting; the treatment of women workers; and problems with the operation of the labour courts and the inadequacy of factory inspections. The ensuing report recommended that all stakeholders pursue the implementation of living wage and the implementation of freedom of association and collective bargaining, with a series of more specific recommendations to the government, brands and unions (AFWA, 2014a). For brands, the latter included the introduction of binding policies mandating the Asia Floor Wage and further efforts to ensure transparency in auditing, while for the government they focussed on effective operation of the courts and security forces, as well as monitoring of violations of the labour law. But while the tribunal event and the report generated some attention to these concerns, Indonesian unions and labour NGOs reported that there was limited follow-up to these interventions nor any notable impact on the state, brands or union campaigns and organisational priorities for securing improvements to wages and working conditions for garment workers in Indonesia.

Indonesian unions' limited engagement and interest in this regional campaign for a living wage also certainly relates to the reality that in Indonesia any kind of wage floor is primarily achieved through the existing minimum wage mechanism. Minimum wages are determined through an annual process led by local tripartite wage boards, which estimated the income needed for workers to achieve a decent standard of living, described as requirements for a decent life (kebutuhan hidup layak (KHL)), represented by a basket of 60 food and non-food components in the calculation of minimum wage. The agreed figure is then presented to the local mayor or district head, and then signed off at the provincial level. Used as a rallying point for street-based protests, this process bolstered union bargaining power and resulted in increases in major industrial districts of up to 50 per cent (Caraway and Ford, 2014). Under pressure from employers, the government passed Regulation No. 78/2015 on wage-setting, which reduced unions' bargaining power by imposing a set formula based on KHL, the inflation rate and GDP (Caraway and Ford, 2016). Under these conditions of heightened political and policy attention to country-specific mechanisms of minimum wage determination, the incentives for national unions to focus their demands around a regional wage remain very weak.

\subsection{Cambodia}

In Cambodia, the AFWA has five member organisations: the Community Legal Education Center; the Cambodian Confederation of Trade Unions; the Cambodian Labour 
ER

39,6

910

Confederation; the Cambodian National Confederation and the National Union Alliance Chamber of Cambodia (AFWA, 2014b). As in Indonesia, the national hub is an NGO, not a union. As in Indonesia, also, the most prominent local intervention by the AFWA has been the organisation of a People's Tribunal in Phnom Penh in February 2012. Aside from wages, the tribunal also pointed to the widespread use of fixed duration contracts in the garment industry, victimization of union leaders and other violations of the right to freedom of association, and restrictions on the ability of workers to demonstrate and strike. The report produced following this process noted that the prevailing conditions and poverty wages in the industry represented a systematic violation of workers' fundamental right to a decent human life. It recommended that Cambodian garment workers receive a wage in the range of US\$185-200 until an Asia Floor Wage can be negotiated, and that unions and labour NGOs in Cambodia should adopt the living wage concept as a central part of their advocacy and bargaining strategies (AFWA, 2012a).

While the tribunal produced a series of specific recommendations for the actions that brands, local employers and the Cambodian Government should take to support the realisation of a living wage for garment workers, the degree of engagement of these actors in the process and its outcomes was limited or non-existent. The Garment Manufacturers' Association of Cambodia refused to attend the tribunal on the basis of a view that it was biased in favour of unions and workers (AFWA, 2012a). Two brands contracting goods from suppliers in Cambodia attended the event and provided statements but AFWA (2012b) deemed the general participation and response of the brands as "inadequate". Reflecting on the initiative, representatives of several of the named member organisations of the AFWA reported that the tribunal was not considered to have had a significant impact on government policy or agencies, or on business practices. Some did, however, believe that it had raised the profile of the term "living wage", noting also that they had at times cited the monthly wage figure produced by the process as an aspirational target in some of their campaigns on wages (interviews, January 2017).

However, as with Indonesia, the same constituent organisations pointed to the lack of followup in subsequent years to consolidate or extend the reach of the living wage as a concept or a viable economic and political demand. Instead, the focus of Cambodian unions in the garment industry has been on the mechanisms, institutions and outcomes of minimum wage-setting (interviews, January 2017). This is especially so because, after years of wage stagnation, there has been sustained worker mobilisation on wages since 2013/2014, when a strike wave and protests resulted in violent street confrontations (Ward and Mouyly, 2016). This event evoked a strong response from the state which, while presiding over a series of wage increases, has sought to now more carefully manage the process by which minimum wages are determined and by passing new labour laws pertaining to trade union registration[8]. Independent and opposition unions report that almost all of their attention on wages was absorbed by campaigns, while pro-government unions are involved in institutional participation or government lobbying around the minimum wage processes and outcomes (interviews, January 2017). None reported any strong commitment, nor sustained organisational engagement, with working for and supporting the campaign to build a regional living wage.

\section{Conclusion}

All global or regional union or advocacy groups inevitably confront challenges when working in and across multiple national contexts. These include the difficulty of resourcing and then sustaining campaigning interventions and developing effective organisational structures across scale, as well as the relative incentives or disincentives for local or national unions to engage in regional or global networks or campaigns. As a consequence, the reach and effect of transnational wage campaigns can only be understood with consideration of the national economic, political and institutional context that drives the strategies and priorities of constituent organisations, governments and industry 
stakeholders. Through its actions and communications, the AFWA has no doubt contributed to increased awareness in the region of the living wage concept and, alongside initiatives and campaigns by other organisations, attention to many non-wage problems that have a negative impact on the labour rights and wellbeing of garment workers in global supply chains. The Asia Floor Wage has gained some traction with international NGOs such as the Fair Labor Association and the Workers Rights Consortium and, as noted earlier, has been adopted as a living wage benchmark by the Fair Wear Foundation (Bhattacharjee and Roy, 2012). However - in Cambodia and Indonesia at least - the campaign has had a minimal effect on the discourse and practice of brands, local companies and government agencies, or even local trade unions.

Efforts towards a common and coordinated regional approach to living wages may continue, but it is unlikely to gain traction in the absence of robust local and regional coalitions of trade unions, which the AFWA itself positions at the very centre of its strategy. The idea of a regional living wage as a long-term aspiration is compatible with local trade union agendas. However, even though the Asia Floor Wage is lower than some other calculations[9] the level at which it is set - in Cambodia's case, at 3.2 times the prevailing minimum wage - means that it is at best peripheral to those unions' organisational strategies and practice. In these circumstances, the main locus of union activity and practice on wages is likely to remain local minimum wage determination institutions and processes. These organisational priorities have a practical logic in light of the relative likelihood of achieving a concrete outcome through mobilisation, lobbying or industrial action, as evidenced by the success of national and sub-national campaigns and worker mobilisations in increasing minimum wages in both Indonesia and Cambodia.

However, ultimately, there remains a gulf between what campaigns and worker mobilisations have produced and what workers actually need - by any definition - in terms of a living wage. Importantly, also, an increase in minimum wages does not guarantee that these wages will actually be delivered: as noted by a recent ILO study, there is widespread noncompliance in the payment of minimum wages in the garment manufacturing industry across the region (Cowgill and Huynh, 2016). Instances where employers do not pay minimum wages, in conjunction with evidence on violations of freedom of association rights and persistent poor working conditions, expose the weakness of government agencies of enforcement and corporate monitoring systems, and points to the important role for independent worker representation and networks of representation across scale in both securing and enforcing real wage gains.

\section{Notes}

1. Authors are listed alphabetically and have contributed equally to the article. Ford's contribution was supported by an Australian Research Council Future Fellowship project entitled 'Trade Unionism and Trade Union Aid in Indonesia, Malaysia and Timor-Leste' (FT120100778). A total of 40 interviews were conducted in March and November 2016 and in January 2017. This core research was supplemented by insights from the interviews with Global Union Federation representatives in Singapore and Geneva, and with representatives of other multi-stakeholder initiatives including the Fair Wear Foundation and the Freedom of Association Protocol, undertaken as part of a multi-year study of Global Union Federations funded by a Discovery Project grant from the Australian Research Council (DP130101650).

2. For a survey of living wage literature, see Werner and Lim (2016). There are only a handful of studies of the living wage initiatives in the garment industry (see Miller and Williams, 2009; Miller and Hohenegger, 2016) or in Asia (see e.g. Bhattacharjee et al., 2009; Merk, 2010), the latter authored by AFWA participants.

3. Purchasing power parity conversion factors are set by the World Bank.

4. The Anker method is used and supported by the Global Living Wage Coalition (GLWC), which is linked to a sustainability and social/environmental certification network (the ISEAL alliance). The ISEAL alliance has committed to supporting a living wage by developing, promoting and 
ER

39,6

912

testing this living wage method. For details, see www.isealalliance.org/our-work/improvingeffectiveness/global-living-wage-coalition.

5. For a detailed account of the GUFs and their operations, see Croucher and Cotton (2011). For a critical overview of the literature on the GUFs, see Ford and Gillan (2015).

6. The ITGLWF was one of three GUFs that merged to form IndustriALL in June 2012.

7. For an overview of these voluntaristic private initiatives in the garment industry, see Esbenshade (2012).

8. In July 2015, AFWA together with other NGOs and trade unions wrote a letter to the President of the National Assembly and other senior government officials in Cambodia urging them not to pass the Trade Union Law and the Law on Associations and NGOs (LANGO) arguing that these laws would restrict freedom of association (AFWA, 2015a).

9. For a higher calculation of a living wage in Cambodia see (Labour Behind the Label and Community Legal Education Centre, 2013).

\section{References}

AFWA (2005), "Towards an Asian floor-level wage campaign in the garment export sector - an analysis of labour and the supply chain in the garment export sector", Asia Floor Wage Alliance, available at: http://asia.floorwage.org/resources/public-statements/first-discussion-paper-onasia-floor-wage-2005 (accessed 25 July 2016).

AFWA (2012a), "People's tribunal: living wage as a fundamental right of Cambodian garment workers", Asia Floor Wage Alliance, Phnom Penh.

AFWA (2012b), "Press statement: from the Asia Floor Wage Alliance", available at: https://afwcam. files.wordpress.com/2012/02/press-conference-statement_20120208.pdf (accessed 25 July 2016).

AFWA (2013), "Steering committee", available at: http://asia.floorwage.org/about/steering-committee (accessed 5 December 2016).

AFWA (2014a), Indonesian People's Tribunal: Living Wage and Decent Working Conditions for Garment Workers as Fundamental Rights, Asian Floor Wage Alliance, Jakarta.

AFWA (2014b), "Members of the Asia Floor Wage Alliance", available at: http://asia.floorwage.org/ about/members (accessed 5 December 2016).

AFWA (2015a), "AFWA protest letter on draft NGO and TU law in Cambodia", available at: https:// cleanclothes.org/livingwage/afw/resources/public-statements/afwa-protest-letter-on-draft-ngoand-tu-law-in-cambodia-1/view (accessed 27 December 2016).

AFWA (2015b), "Asia floor wage: what is it and why do we need one?", available at: http:/asia. floorwage.org/what (accessed 26 July 2016).

AFWA (2015c), "Calculating a living wage", available at: http://asia.floorwage.org/calculating-aliving-wage (accessed 26 July 2016).

AFWA, GUFs and ILO (2014), "Statement from first dialogue of AFWA with Global Union Federations and the ILO”, Asia Floor Wage Alliance, Hong Kong, available at: http://asia.floorwage.org/ resources/global-unions/statement-from-first-dialogue-of-afwa-with-global-union-federationsand-the-ilo-2014 (accessed 26 July 2016).

Anker, R. (2011), "Estimating a living wage: a methodological review”, ILO Working Paper Conditions of Work and Employment Series No. 29, ILO, Geneva.

Anker, R. and Anker, M. (2017), Living Wages around the World: Manual for Measurement, Edward Elgar Publishing, Sussex.

Barria, S. (2014), National People's Tribunals on Living Wage for Garment Workers in Asia, Asia Floor Wage Alliance, New Delhi.

Bhattacharjee, A. and Roy, A. (2012), "Asia floor wage and global industrial collective bargaining”, International Journal of Labour Research, Vol. 4 No. 1, pp. 67-83.

Bhattacharjee, A. and Roy, A. (2015a), "The Asia Floor Wage strategy", in Bhattacharjee, A., Roy, A., Bhardwaj, K. et al. (Eds), Towards an Asia Floor Wage, Asia Floor Wage, Actionaid, South Solidarity Initiative, Bangalore, pp. 42-51. 
Bhattacharjee, A. and Roy, A. (2015b), "Bargaining in the global commodity chain: the Asia Floor Wage Alliance", in Pijl, K.V.D. (Ed.), Handbook of the International Political Economy of Production, Edward Elgar Publishing, Sussex, pp. 334-351.

Bhattacharjee, A., Gupta, S. and Luce, S. (2009), "Raising the floor: the movement for a living wage in Asia”, New Labor Forum, Vol. 18 No. 3, pp. 72-81.

Braun, R. and Gearhart, J. (2004), "Who should code your conduct? Trade union and NGO differences in the fight for workers' rights", Development in Practice, Vol. 14 Nos 1-2, pp. 183-196.

Caraway, T., Ford, M. and Nguyen, O. (2015), "Maxing out the minimum wage in Indonesia”, paper presented at the APSA Annual Meeting, San Francisco, CA, 3-6 September.

Caraway, T.L. and Ford, M. (2014), "Labor and politics under oligarchy", in Ford, M. and Pepinsky, T.B. (Eds), Beyond Oligarchy? Critical Exchanges on Political Power and Material Inequality in Indonesia, Cornell University Southeast Asia Program, Ithaca, NY, pp. 139-156.

Caraway, T.L. and Ford, M. (2016), "United in disappointment", Inside Indonesia, Vol. 123, available at: www.insideindonesia.org/united-in-disappointment-2 (accessed 7 December 2016).

Cowgill, M. and Huynh, P. (2016), Weak Minimum Wage Compliance in Asia's Garment Industry, ILO Regional Office for Asia and Pacific, Bangkok.

Croucher, R. and Cotton, E. (2011), Global Unions, Global Business: Global Union Federations and International Business, 2nd ed., Libri Publishing, London.

Egels-Zandén, N. and Hyllman, P. (2006), "Exploring the effects of union-NGO relationships on corporate responsibility: the case of the Swedish clean clothes campaign", Journal of Business Ethics, Vol. 64 No. 3, pp. 303-316.

Esbenshade, J. (2012), "A review of private regulation: codes and monitoring in the apparel industry", Sociology Compass, Vol. 6 No. 7, pp. 541-556.

ETI (2013), "Living wage: roundup of key current resources and initiatives", Ethical Trading Initiative, available at: www.ethicaltrade.org/resources/living-wage-resource-roundup (accessed 5 December 2016).

Flanagan, R.J. (2008), “The changing structure of collective bargaining”, in Blyton, P., Bacon, N., Fiorito, J. and Heery, E. (Eds), The Sage Handbook of Industrial Relations, Sage, London, pp. 406-419.

Ford, M. and Gillan, M. (2015), "The Global Union Federations in international industrial relations: a critical review", Journal of Industrial Relations, Vol. 57 No. 3, pp. 456-475.

Ford, M. and Gillan, M. (2016), "Employment relations and the state in Southeast Asia”, Journal of Industrial Relations, Vol. 58 No. 2, pp. 167-182.

Government of India (2012), Report on the Working of the Minimum Wages Act, 1948 for the Year 2010, Ministry of Labour and Employment, Labour Bureau, Chandigarh and Shimla.

Holdcroft, J. (2015), “Transforming supply chain industrial relations”, International Journal of Labour Research, Vol. 7 Nos 1/2, pp. 95-104.

ILO (2015a), "Growth continues for Cambodia's garment and footwear sector", available at: www.ilo. $\mathrm{org} / \mathrm{wcmsp} 5 /$ groups/public/—asia/—ro-bangkok/—sro-bangkok/documents/publication/ wcms_383562.pdf (accessed 19 February 2017).

ILO (2015b), "Minimum wages in the global garment industry: update for 2015", available at: www.ilo. org/asia/whatwedo/publications/WCMS_436867/lang-en/index.htm (accessed 19 February 2017).

ILOStat (2017a), "Employment by sex and economic activity - selected ISIC level 2 (thousands)", available at: www.ilo.org/ilostat (accessed 19 February 2017).

ILOStat (2017b), "Employment by sex and economic activity (thousands)", available at: www.ilo.org/ ilostat (accessed 19 February 2017).

IndustriALL (2014), "IndustriALL regional living wage workshop", available at: www.industriallunion.org/events/industriall-regional-living-wage-workshop (accessed 26 July 2016).

IndustriALL (2015), "Mobilizing for living wages", available at: www.industriall-union.org/mobilizingfor-living-wages (accessed 26 July 2016).

ITGLWF (2012), "Background Paper: Global Conference on Bargaining for a Living Wage", 17-18 June, Copenhagen, ITGLWF, Brussels.
In search of a living wage in Southeast Asia 
ER

39,6

914

Labour Behind the Label and Community Legal Education Centre (2013), "Shop "til they drop", available at: http://labourbehindthelabel.net/wp-content/uploads/2015/10/shoptiltheydrop.pdf (accessed 26 July 2016).

McMullen, A., Luginbühl, C., Nolan, K., Crabbé, C. and Ajaltouni, N. (2014), “Tailored wages”, Clean Clothes Campaign, available at: www.cleanclothes.org/livingwage/tailoredwages/tailored-wagereport-pdf (accessed 26 July 2016).

Maquila Solidarity Network (2014), "Global survey of living wage initiatives", available at: http://en. archive.maquilasolidarity.org/node/1229 (accessed 16 February 2017).

Merk, J. (2009), Stitching A Decent Wage Across Borders: The Asia Floor Wage Proposal, Asia Floor Wage Alliance, New Delhi.

Merk, J. (2010), "Cross-border wage struggles in the global garment industry: the campaign for an Asia Floor Wage", in Bieler, A. and Lindberg, I. (Eds), Global Restructuring, Labour and the Challenges for Transnational Solidarity: Rethinking Globalizations, Routledge, New York, NY, pp. 116-130.

Merk, J. (2014), Living Wage in Asia, Clean Clothes Campaign, New Delhi.

Miller, D. and Hohenegger, K. (2016), "Redistributing value added towards labour in apparel supply chains: tackling low wages through purchasing practices", Conditions of Work and Employment Series No. 83, ILO, Geneva.

Miller, D. and Williams, P. (2009), "What price a living wage? Implementation issues in the quest for decent wages in the global apparel sector", Global Social Policy, Vol. 9 No. 1, pp. 99-125.

NIS Cambodia (2017), "The labour force in relation to the working age population (15-64 years), 2013", available at: www.nis.gov.kh/index.php/en/find-statistic/social-statistics/cses/cses-tables (accessed 19 February 2017).

Parker, J., Arrowsmith, J., Fells, R. and Prowse, P. (2016), "The living wage: concepts, contexts and future concerns", Labour \& Industry, Vol. 26 No. 1, pp. 1-7.

Pernicka, S. and Glassner, V. (2014), "Transnational trade union strategies towards European wage policy: a neo-institutional framework", European Journal of Industrial Relations, Vol. 20 No. 4, pp. 317-334.

Roy, A. (2015), "The Asia floor wage alliance”, (A. Roy interviewed by de Goei, T. and Crabbé, C.), Living Wage Now!, Clean Clothes Campaign.

van Klaveren, M., Gregory, D. and Schulten, T. (2015), Minimum Wages, Collective Bargaining and Economic Development in Asia and Europe: A Labour Perspective, Palgrave MacMillan, London.

Ward, K. and Mouyly, V. (2016), "Employment relations and political transition in Cambodia", Journal of Industrial Relations, Vol. 58 No. 2, pp. 258-272.

Werner, A. and Lim, M. (2016), "The ethics of the living wage: a review and research agenda”, Journal of Business Ethics, Vol. 137 No. 3, pp. 433-447.

World Bank (2017a), "Health nutrition and population statistics: population estimates and projections", available at: http://databank.worldbank.org/data/reports.aspx?source=Health $\% 20$ Nutrition $\%$ 20and $\%$ 20Population $\% 20$ Statistics: $\% 20$ Population $\%$ 20estimates $\% 20$ and $\%$ 20projections (accessed 19 February 2017).

World Bank (2017b), "World Development Indicators: structure of output", available at: http:// wdi.worldbank.org/table/4.2\# (accessed 19 February 2017).

World Trade Organization (2017), "Merchandise trade”, available at: www.wto.org/english/res_e/ statis_e/merch_trade_stat_e.htm (accessed 19 Februray 2017).

\section{Corresponding author}

Michael Gillan can be contacted at: Michael.Gillan@uwa.edu.au

For instructions on how to order reprints of this article, please visit our website:

www.emeraldgrouppublishing.com/licensing/reprints.htm

Or contact us for further details: permissions@emeraldinsight.com 